\title{
Pengaruh Religiusitas Jamaah Masjid Az-Zuhud Petanahan Kebumen Terhadap Perilaku Toleransi Beragama dengan Kepribadian yang Dimilikinya
}

\author{
Saliyo \\ STAIN Kudus \\ Saliyo41876@gmail.com
}

\begin{abstract}
This research aimed to know; influence of one's religiosity to its tolerance behavior, to know the personality variables as a moderator variable between variable tolerance behavior towards one's religiosity. This research is quantitative. The number of research subjects 75 respondents group of yasinan Az-Zubud Mosque Village Petanahan Kebumen. The analysis used by using computerized regression analysis services. Sampling data using probability sampling with random sampling. Data collection using scale. The results showed that no significant relationship between religiosity and religious tolerance a person against person. There is a significant relationship when the personality becomes a moderator variable between religiosity toward tolerance. This means that the religiosity interact with personality as moderator variables, the higher the effect the bigher the religiosity of someone's personality influence the behavior of tolerance.
\end{abstract}

Keywords: Religiosity, personality, and behavior of tolerance.

\begin{abstract}
Abstrak
Penelitian ini dilakukan memiliki tujuan untuk mengetabui : pertama pengaruh religiusitas seseorang terhadap perilaku toleransi yang dimilikinya. Kedua mengetahui variabel kepribadian sebagai variabel moderator antara variabel religiusitas terhadap perilaku toleransi seseorang. Penelitian ini merupakan penelitian kuantitatif. Jumlah subjek penelitian 75 responden jamaab yasinan Masjid Az-Zubud Desa Petanahan Kecamatan Petanahan Kabupaten Kebumen. Analisis yang digunakan dengan menggunakan jasa komputer analisis regresi. Pengambilan sampling data menggunakan probability sampling dengan random sampling. Pengambilan data dengan menggunakan skala. Hasil penelitian menunjukan bahwa tidak ada hubungan yang signifikan antara religiusitas seseorang terhadap perilaku toleransi beragama seseorang. Ada bubungan yang signifikan ketika kepribadian menjadi variabel moderator antara religiusitas terhadap perilaku toleransi. Artinya semakin religiusitas berinteraksi dengan kepribadian sebagai variabel moderator, maka semakin tinggi pengarub religiusitas seseorang semakin tinggi pula pengaruh kepribadian terbadap perilaku toleransi.
\end{abstract}

Kata kunci : Religiusitas, Kepribadian, dan Perilaku Toleransi.

Permalink/DOI: http://dx.doi.org/10.18326/infsl3v12i1.65-84 


\section{Pendahuluan}

Kajian toleransi dan intoleransi termasuk kajian psikologi agama. Agama dikaitkan dengan ilmu psikologi bertujuan meningkatkan pemahaman agama. Tujuan psikologi agama sebagai pisau analisis tidak untuk menghancurkan agama atau membuat agama baru, tetapi paling tidak dapat merubah perilaku yang lebih baik. Perilaku tersebut adalah perilaku toleransi dalam beragama (Thouless, 1995: 239-240).

Bukti dari perilaku toleransi terlihat pada kemajemukan di Indonesia yang dipahami para dai Islam dalam menyebarkan agama penuh dengan rahmat tidak paksaan maupun permusuhan. Hal tersebut dilakukan oleh para wali yang mengislamkan tanah Jawa. Penyebaran Islam telah sempurna abad ke 16. Peristiwa tersebut seiring berdirinya kerajaan Islam di Demak. Ukuran sempurna karena sebagian besar masyarakat Jawa telah memeluk agama Islam (Simuh, $2002:$ 2002).

Kehidupan toleransi merupakan cita-cita sosial Islam. Hal tersebut dimulai dari perjuangan para dai dengan menumbuhsuburkan aspek-aspek akidah dan etika dalam diri pemeluknya. Ia dimulai dengan pendidikan kejiwaan bagi setiap pribadi, keluarga, dan masyarakat yang menciptakan hubungan serasi antara semua anggota masyarakat (Shihab, 1992 : 342).

Kehidupan yang damai saling menghargai, setiap perbedaan merupakan dambaan bagi setiap manusia. Perbedaan manusia merupakan sunatullah. Perbedaan tersebut dapat dilihat dari suku, agama, dan ras. Dimanapun manusia hidup, perbedaan merupakan sebuah keniscayaan. Hal yang demikian merupakan pengembangan dan menjujung tinggi kehidupan yang toleran (Ismail, 2012 : 1-2).

Ulasan di atas dapat dipahami bahwa tokoh agama dalam menjalankan peran sebagai da'i sangat penting dengan menjalankan dan mengembangkan perilaku toleransi. Lebih penting lagi bahwa seorang da'i memberikan contoh kepada umatnya bagaimana bisa berperilaku tasamuh dalam perbedaan. Setiap manusia memiliki perbedaan baik dari warna kulitnya, ras, kepercayaan dan sukunya, 
namun perbedaan bukan untuk dibesar-besarkan. Perbedaan merupakan warna yang unik dan indah apabila satu sama lain saling menghargai dan menghormati.

Agama merupakan bagian dari kehidupan seseorang dalam berperilaku yang mempengaruhi psikis seseorang. Agama juga merupakan bagian dari identitas kehidupan seseorang. Menurut Pargament dan Mahone bahwa agama merupakan cara untuk mencari sesuatu yang ada pada yang Maha Tinggi yang menjadi bagian dari motivasi seseorang. Sisi lain agama juga menyadarkan pada pemeluknya untuk selalu berpacu untuk berprestasi. Agama menyadarkan pada pemeluknya untuk dapat mengambil makna dan memaksimalkan kemampuan yang dimilikinya untuk mencapai tujuan dan kestabilan emosi yang dimilikinya (Heaven \& Ciarrochi, 2007 : 681).

Ada penelitian meta analisis dari 21 sampel dari lima belas Negara dengan total $\mathrm{N}=8551$ dengan menggunakan nilainilai model Schwartz yang meneliti arti penting agama berkaitan dengan atribut nilai. Hasil penelitian menunjukan bahwa seseorang yang memeluk agama memiliki kecenderungan memiliki nilai-nilai perilaku yang bermartabat baik secara individual maupun secara kelompok. Nilai-nilai tersebut terdiri dari nilai tradisi, penyesuaian, dan keamanan. Sebaliknya pada nilai-nilai yang tidak disukai yaitu nilai-nilai keterbukaan sebagai stimulasi dan secara langsung dimiliki oleh pemeluk agama tersebut. Nilai-nilai yang lain yang dimiliki oleh pemeluk agama adalah hubungan dirinya dengan Tuhan melalui penanaman nilai-nilai kebajikan pada dirinya ketika berbuat untuk orang lain ataupun untuk dirinya sendiri. Nilai-nilai yang lain yang dimiliki oleh pemeluk agama adalah tidak senang menikmati kehidupan hanya untuk diri sendiri. Mereka pemeluk agama dalam hidupnya tidak hanya mencari prestasi ataupun kekuatan dalam hidupnya. Nilai nilai tersebut tidak hanya ditemukan pada agama tertentu, tetapi oleh semua agama Islam, Kristen, Hindu Budha dan lain sebagainya (Saroglou et al, 2004 : 721).

Berdasarkan hasil penelitian di Eropa bahwa kecenderungan seseorang memiliki perilaku intoleransi. Sikap-sikap intoleransi tersebut meliputi karena adanya perbedaan ras, warga muslim, 
imigran, warga Yahudi, bangsa Gipsi dan orang-orang yang memiliki perilaku homoseksual. Hasil penelitian di Eropa dilaporkan bahwa perlakuan intoleran pada perbedaaan ras cenderung stabil yaitu naik juga tidak, menurun juga tidak. Perlakuan tidak toleran yang meningkat ada perlakuan pada warga muslim, immigran dan bangsa Gipsi. Perlakuan tidak toleransi di Eropa yang menurun adalah perlakuan pada warga Yahudi dan perilaku homoseksual.

Adapun beberapa faktor yang menyebabkan terjadinya perilaku intoleran di Eropa ada beberapa hal. Faktor-faktor tersebut adalah ekonomi, demografik, sosial politik, dan budaya. Faktor ekonomi menjadikan sebab intoleransi karena banyaknya pengangguran, ketimpangan ekonomi antar warga Negara yang tajam, dan persepsi atas ancaman ekonomi pada lembaga atau ras tertentu. Faktor demografik yang dapat menyebabkan terjadinya perilaku intoleransi adalah perbedaan kelas sosial, umur, pendidikan, dan orientasi politik individu. Faktor sosial politik yang dapat menyebabkan perilaku intoleransi adalah keanggotaan seseorang pada politik tertentu dan capaian kesejahteraan. Terakhir faktor budaya. Faktor budaya perlakuan tidak toleransi dilakukan pada seseorang di luar kelompoknya. Perlakuan tersebut karena adanya persepsi pada etnik tertentu, dan kepercayaan sosial yang tidak baik (Rubin et al, 2014 : 16-17).

\section{Kajian Teori}

Kehidupan yang damai saling menghargai, setiap perbedaan merupakan dambaan bagi setiap manusia. Perbedaan manusia merupakan sunatullah. Perbedaan tersebut dapat dilihat dari suku, agama, dan ras. Dimanapun manusia hidup, perbedaan merupakan sebuah keniscayaan. Kesimpulannya dimanapun manusia hidup di muka bumi tidak ada yang tunggal. Kehidupan yang demikian tidak dipungkiri bahwa terjadinya perbedaan pikiran, sikap dapat dimungkinkan akan terjadinya konflik. Hal yang demikian pengembangan dan menjujung tinggi kehidupan yang toleran merupakan salah satu cara untuk menciptakan kehidupan yang damai dan harmonis (Ismail, 2012 : 1-2). 
Toleransi merupakan sifat atau sikap toleran dua kelompok atau lebih yang berbeda yang saling berhubunngan dengan penuh, dengan batasan atau ukuran yang diperbolehkan, dan penyimpangan yang masih diterima (Tim Redaksi Kamus Besar Bahasa Indonesia Edis Ketiga, 2003 : 1204). Memahami makna toleransi dapat dibaca pada deklarasi UNESCO pada tanggal 16 Nopember 1995. Pertama bahwa toleransi memiliki makna menghormati, menerima dan memberikan apresiasi dalam setiap perbedaan budaya. Kedua toleransi adalah tidak memberikan konsesi, tetapi menghormati dan menghargai adanya perbedaan. Ketiga toleransi memiliki makna bertanggungjawab, dan menegakan hak asasi manusia dan pluralisme dalam budaya serta menghargai demokrasi dan hukum. Keempat konsisten menerima hak asasi manusia serta melakukan praktik toleransi dalam kehidupannya (Asy'arie, 205 : 360).

Perilaku toleransi seseorang dapat dipengaruhi pada kepribadian seseorang. Kepribadian merupakan watak yang dimiliki seseorang yang unik dan dibawa ketika berinteraksi dengan yang lain. Menurut Mc Kenna menjelaskan bahwa kepribadian didefinisikan sebagai sesuatu yang abstrak yang melekat pada diri seseorang untuk menentukan sebuah pilihan perilaku ketika berinteraksi dalam sebuah lingkungan. Walaupun demikian kepribadian dapat diteliti, diobservasi. Alasannya karena kepribadian secara langsung berpengaruh terhadap pada individu tersebut. Karakteristik yang demikian yang dimiliki oleh seseorang dinamakan kepribadian. Setiap orang memiliki kepribadian masing-masing dan memiliki keunikan tersendiri (Ekinci et al, 2000 : 5).

Dalam kehidupan beragama perbedaan tidak jarang menyulut adanya konflik bahkan peperangan. Seringkali dalam hal yang kecil dan sepele perbedaan agama menjadi akar permusuhan. Patut disayangkan peperangan ataupun konflik tersebut biasanya dibungkus atas nama Tuhan atau agama. Kondisi semacam ini sebenarnya merupakan kondisi seseorang yang matang atau belum matang dalam beragama. Kematangan beragama berkaitan dengan kajian psikologi yaitu kepribadian seseorang. Seseorang yang matang beragama maka orang tersebut sering melakukan tindakan yang positif. Menurut Clark bahwa seseorang yang matang dalam beragama memiliki pengalaman perjumpaan dengan Tuhan dan berpengaruh dalam tindakan kehidupan sehari-hari. Orang tersebut 
berusaha menyelaraskan kehidupan dengan harmonis bersama Tuhan. Menurut Clark ada tiga ciri kepribadian seseorang yang matang dalam beragama. Pertama orang tersebut dalam beragama kritis, otonom, kreatif dalam beragama. Kedua memperluas perhatiannya di luar. Ketiga tidak puas dengan hal-hal yag ritual dan verbal (Ismail, $2012: 2-4$ ).

Keyakinan agama berkaitan dengan perilaku yang menyehatkan dengan kesehatan mental, kesejahteraan psikologis dan perilaku sosial. Sebagai catatan bahwa seseorang yang memiliki religiusitas yang baik ketaatan beragama berpengaruh terhadap panjang umur seseorang, berkurangnya depresi, meraih prestasi yang lebih baik, dan berkurangnya untuk berbuat kriminal serta perkawinan yang memuaskan. Sisi lain agama juga berkaitan dengan kontrol diri dalam setiap akan melakukan sesuatu (Carter et al, 2012).

Agama atau religiusitas juga akan mempengaruhi watak kepribadian seseorang. Menurut Glock dan Stark bahwa religiusitas merupakan sistem yang menimbulkan nilai, keyakinan, dan sistem perilaku yang terlembaga yang semuanya terpusat pada persoalanpersoalan yang dihayati sebagai sesuatu yang maknawi. Religiusitas merupakan komitmen dengan agama yang diyakininya yang dapat terlihat dalam kehidupan sehari-hari baik yang tampak ataupun tidak tampak (Hasan, 2013 : 12).

Religiusitas dalam Islam berkaitan dengan hadist nabi yang diriwayatkan oleh Muslim, Tirmidzi, Abu Dawud dan Nasai. Hadist tersebut menjelaskan tentang rukun iman, rukun Islam dan ikhsan. Iman dalam hadist tersebut iman kepada Allah, Malaikat, kitabkitabNya, RasulNya, dan takdir Allah. Takdir tersebut meliputi takdir yang baik dan takdir buruk. Selanjutnya tentang rukun Islam. Rukun Islam tersebut meliputi mendirikan shalat, menunaikan zakat, menjalankan puasa di bulan Ramadhan, dan menjalankan haji. Selanjutnya adalah ikhsan. Ikhsan adalah seseorang yang beribadah seolah-olah dapat melihat Allah, apabila tidak mampu maka Allah yang melihatnya (Saliyo, 2017 : 80-81).

Berkaitan dengan variabel penelitian ini yaitu religiusitas, kepribadian dan perilaku toleransi dapat membaca beberapa hasil penelitian. Hasil penelitian menunjukan bahwa religiusitas tidak 
berpengaruh secara langsung terhadap agresi relasional mahasiswa, tetapi religiusitas berpengaruh secara langsung terhadap perilaku pemaafan. Sisi lain perilaku pemaafan mempunyai pengaruh langsung terhadap relasi agresional (Hasan, 2013 : 10).

Hasil investigasi penelitian menunjukan bahwa ada hubungan religiusitas dan kepribadian yang berpengaruh terhadap nilainiliai etika penganut agama tersebut. Tema-tema tersebut banyak dikaji dalam psikologi agama. Lebih lanjut lagi tema-tema tersebut juga memberikan inspirasi mengembangkan kajian pada psikologi agama berkaitan dengan pandangan psikoanalisis, psikologi sosial, dan psikologi kognitif. Selanjutnya kajian tersebut diharapkan berkonstribusi pada pengembangan psikologi agama, psikologi kepribadian untuk dapat menyajikan taksanomi kepribadian seseorang (Saroglou \& Jaspard, th : 41).

Penelitian yang lain menunjukan bahwa kepribadian yang bermoral dan identitas moral berhubungan dengan etika individu. Artinya seseorang yang memiliki kepribadian yang baik dan identitas yang baik (agama) akan berpengaruh pada perilakunya dengan menjunjung tinggi etika kehidupan. Penelitian selanjutnya bahwa idiologi menjadi variabel mediator antara kepribadian dan identitas moral. Artinya bahwa semakin baik kepribadian seseorang dengan idiologi dimilikinya maka orang tersebut akan memiliki perilaku moral yang baik (Mc Ferran et al, 2010 : 35).

Berangkat dari uraian di atas peneliti mengajukan kerangka model penelitian kuantitatif dengan variabel moderator.

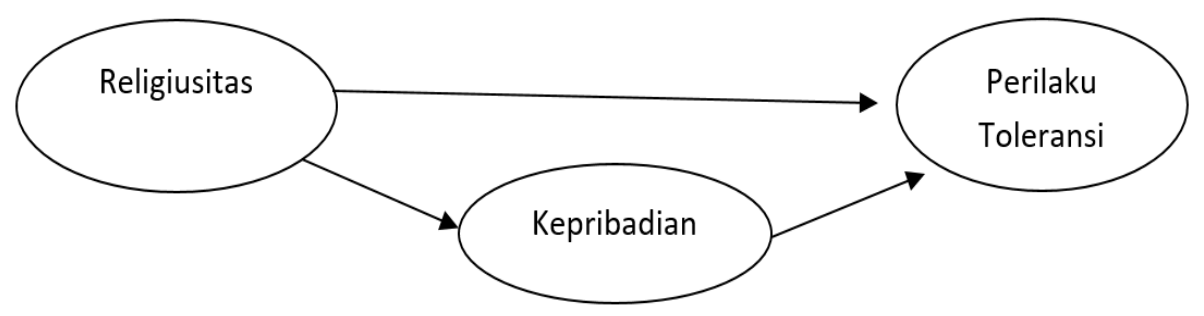

Gambar : 1

Model regresi dengan variabel independent religiusitas, variabel dependent perilaku toleransi dan variabel moderator kepribadian. 


\section{Metode Penelitian}

Penelitian ini merupakan penelitian kuantitatif. Pengumpulan sampling data dengan menggunakan probability sampling dengan teknik random sampling, sedangkan pengambilan datanya dengan skala. Skala yang digunakan adalah skala Likert. Skala tersebut dibuat dari teori religiusitas, kepribadian dan perilaku toleransi beragama. Aspek-aspek religiusitas dalam pembuatan skala diambil dari religiusitas keberagamaan Islam meliputi iman, Islam dan ikhsan. Aspek-aspek kepribadian dalam pembuatan skala diambil dari Clark. Menurutnya ada tiga ciri kepribadian seseorang yang matang dalam beragama. Pertama orang tersebut dalam beragama kritis, otonom, kreatif dalam beragama. Kedua memperluas perhatiannya di luar. Ketiga tidak puas dengan hal-hal yag ritual dan verbal. Selanjutnya pembuatan skala perilaku toleransi diambil dari deklarasi UNESCO pada tanggal 16 Nopember 1995. Pertama bahwa toleransi memiliki makna menghormati, menerima dan memberikan apresiaisi dalam setiap perbedaan budaya. Kedua toleransi adalah tidak memberikan konsesi, tetapi menghormati dan menghargai adanya perbedaan. Ketiga toleransi memiliki makna bertanggungjawab, dan menegakan hak asasi manusia dan pluralisme dalam budaya serta menghargai demokrasi dan hukum. Keempat konsisten menerima hak asasi manusia serta melakukan praktik toleransi dalam kehidupannya.

Jumlah Responden terdiri dari $\mathrm{N}=75$ orang jamaah yasinan Masjid Az-Zuhud Desa Petanahan Kecamatan Petanahan Kabupaten Kebumen. Analisis data dengan menggunakan jasa komputer SPSS 16 analisis regresi. Uji yang dilakukan meliputi uji validitas reliabilitas, uji prasyarat dan uji regresi uji variabel moderator dengan uji interaksi. 


\section{Hasil Penelitian}

Responden ditinjau dari jenis kelamin dan umur

Tabel : 1

Responden data penelitian jenis kelamin

\begin{tabular}{llll}
\hline No & Jenis Kelamin & Jumlah & $\%$ \\
\hline 1 & Laki-laki & 53 & 70,7 \\
2 & Perempuan & 22 & 29,3 \\
\hline
\end{tabular}

Berdasarkan hasil analisis statistik pada tabel 1 dapat disimpulkan bahwa responden penelitian ini terdiri dari jenis kelamin laki-laki berjumlah 53 orang atau 70,7\%. Jenis kelamin perempuan berjumlah 22 orang atau 29, 3\%.

Tabel : 2

Responden data penelitian umur

\begin{tabular}{llll}
\hline No & Umur & Jumlah & $\%$ \\
\hline 1 & $20-35$ & 24 & 32 \\
2 & $35-45$ & 18 & 24 \\
3 & $45-65$ & 33 & 44 \\
\hline
\end{tabular}

Berdasarkan hasil analisis statistik pada tabel 2 dapat disimpulkan bahwa responden penelitian ini terdiri dari umur 20-35 berjumlah 24 orang atau 32\%. Responden umur 35-45 berjumlah 18 orang atau 24\%, dan umur 45-65 berjumlah 33 orang atau $44 \%$. 
Uji validitas dan reliabilitas

\section{Tabel : 3}

\section{Uji validitas}

\begin{tabular}{llll}
\hline No & Variabel & Nilai korelasi & Jumlah aitem yang valid \\
\hline 1 & Religiusitas & $>0,30$ & 18 \\
2 & Kepribadian & $>0,30$ & 19 \\
3 & Perilaku Toleransi & $>0,30$ & 19 \\
\hline
\end{tabular}

Berdasarkan hasil analisis statistik pada tabel 3 dapat disimpulkan bahwa validitas variabel religiusitas 18 aitem, validitas variabel kepribadian 19 aitem, dan validitas variabel perilaku toleransi berjumlah 19 aitem.

Tabel : 4

\section{Uji reliabilitas}

\begin{tabular}{llcl}
\hline No & Variabel & $\begin{array}{c}\text { Nilai alpha } \\
\text { cronbach }\end{array}$ & Jumlah aitem yang valid \\
\hline 1 & Religiusitas & $>0,60=0,817$ & Reliabel \\
2 & Kepribadian & $>0,60=0,607$ & Reliabel \\
3 & Perilaku Toleransi & $>0,60=0,754$ & Reliabel \\
\hline
\end{tabular}

Berdasarkan hasil analisis statistik pada tabel 4 dapat disimpulkan bahwa variabel religiusitas, variabel kepribadian, dan variabel perilaku toleransi reliable

Uji normalitas dan linieritas

Tabel : 5

Uji normalitas

\begin{tabular}{llll}
\hline No & Variabel & $\begin{array}{c}\text { Nilai Kolmogorov- } \\
\text { Smirnov }\end{array}$ & Keterangan \\
\hline 1 & Religiusitas & $1,043,>0,05=0,227$ & Normal \\
2 & Kepribadian & $0,850,>0,05=0,465$ & Normal \\
3 & Perilaku Toleransi & $0,595,>0,05=0,871$ & Normal \\
\hline
\end{tabular}


Berdasarkan hasil analisis statistik pada tabel 5 dapat dilihat dari nilai Kolmogorov Smirnov disimpulkan bahwa variabel religiusitas, variabel kepribadian, dan variabel perilaku toleransi datanya menunjukan normal.

Tabel : 6

Uji linieritas Variabel Toleransi-Religiusitas

\begin{tabular}{llrl}
\hline No & Nilai signifikansi & Nilai & Keterangan \\
\hline 1 & Combinatied $=\mathrm{p}>0,05$ & 0,766 & Linier Murni \\
2 & Deviation from Linierity $=$ & 0,724 & Linier Murni \\
3 & $(\mathrm{p}>0,05)$ & 0,648 & Linier Kuadratik Murni \\
& Linearity $=(\mathrm{p}>0,05)$ & &
\end{tabular}

Berdasarkan hasil analisis statistik pada tabel 6 dapat disimpulkan bahwa variabel religiusitas, dan variabel perilaku toleransi dapat dikatakan bahwa dilihat dari nilai Combinated dan Deviation from Linierity memiliki linier murni. Dilihat dari nilai Linearity menunjukan linier kuadratik murni.

Tabel : 7

Uji linieritas Toleransi-Kepribadian

\begin{tabular}{llcl}
\hline No & Nilai signifikansi & Nilai & Keterangan \\
\hline 1 & Combinatied $=\mathrm{p}>0,05$ & 0,631 & Linier Murni \\
2 & Deviation from Linierity & 0,627 & Linier Murni \\
3 & $=(\mathrm{p}>0,05)$ & 0,358 & Linier Kuadratik Murni \\
& Linearity $=(\mathrm{p}>0,05)$ & &
\end{tabular}

Berdasarkan hasil analisis statistik pada tabel 7 dapat disimpulkan bahwa variabel kepribadian, dan variabel sikap toleransi dapat dikatakan bahwa dilihat dari nilai Combinated dan Deviation from Linierity menunjukan linier murni. Dilihat dari nilai Linearity menunjukan linier kuadratik murni. 


\section{Analisis hipotesis}

Ada pengaruh secara langsung religiusitas terhadap perilaku toleransi seseorang. Semakin tinggi tingkat religiusitas seseorang, maka semakin tinggi perilaku toleransi orang tersebut.

Berdasarkan hasil analisis statistik regresi bahwa nilai menunjukan $\mathrm{t}=2,292$ dengan nilai signifikansi $\mathrm{p}=0,025(\mathrm{p}<$ $0,01)$. Hasil tersebut menunjukan bahwa religius seseorang tidak berpengaruh terhadap perilaku toleransi seseorang. Selanjutnya melihat hasil analisis statistik nilai $\mathrm{R}$ regresi $=0,115$. Nilai tersebut menunjukan bahwa hubungan religiusitas seseorang terhadap perilaku toleransi sangat lemah. Religiusitas memprediksi perilaku tolerasnsi dengan hasil analisis statistik nilai $R$ Square menunjukan $\left(R^{2}\right)=0$, 013. Nilai tersebut menunjukan bahwa religiusitas memberikan konstribusi pada perilaku toleransi sebesar 13\%. Nilai tersebut menunjukan bahwa ada variabel yang lain yang memberikan konstribusi lebih besar pada perilaku toleransi seseorang.

Persamaan nilai regresi nilai konstanta sebesar 40, 633 nilai tersebut memiliki makna jika semua variabel independen memiliki nilai 0 (nol) maka nilai variabel perilaku toleransi sebesar 40, 633. Nilai tersebut memiliki makna bahwa sikap toleransi responden penelitian dengan mengabaikan religiusitas telah memiliki nilai sebesar 40, 633. Nilai tersebut menunjukan bahwa selain peran religiusitas, terdapat peran variabel lain terhadap sikap toleransi responden penelitian.

Nilai koefisien regresi untuk variabel religiusitas sebesar 0,213. Nilai tersebut memiliki makna bahwa ada peningkatan satu poin religiusitas akan meningkatkan perilaku toleransi sebesar 0,213. Nilai tersebut memiliki makna bahwa semakin tinggi religiusitas responden, maka semakin tinggi perilaku toleransi responden. Responden memiliki religiusitas yang tinggi akan meningkatkan sikap toleransi responden tersebut, dibandingkan dengan responden yang tidak memiliki perilaku toleransi yang tinggi. Hasil tersebut dapat disimpulkan terdapat hubungan positif antara religiusitas dengan perilaku toleransi responden. 
Berdasarkan hasil analisis statistik nilai beta (B) religiusitas mampu menjadi prediktor perilaku toleransi tidak signifikan $(\mathrm{p}<$ 0,01) dengan nilai beta (B) sebesar 0,115.

Ada pengaruh variabel independen religiusitas yang dimoderatori dengan variabel kepribadian seseorang terhadap perilaku toleransi beragama. Semakin tinggi berpengaruh religiusitas terhadap perilaku toleransi seseorang maka semakin tinggi pengaruh kepribadian seseorang terhadap perilaku toleransi orang tersebut. Sebaliknya semakin rendah pengaruh religiusitas terhadap perilaku toleransi seseorang maka semakin rendah pengaruh kepribadian seseorang terhadap perilaku toleransi orang tersebut.

Berdasarkan hasil analisis statistik regresi menunjukan bahwa nilai $\mathrm{F}=2,274$ dengan nilai signifikansi $\mathrm{p}=0,000(\mathrm{p}<0,01)$. Hasil tersebut menunjukan bahwa religiusitas dan kepribadian seseorang berpengaruh terhadap perilaku toleransi seseorang. Dengan demikian maka model regresi dapat digunakan untuk memprediksi perilaku toleransi. Artinya bahwa religiusitas, kepribadian, dan variabel moderat secara bersama-sama berpengaruh terhadap perilaku toleransi seseorang.

Selanjutnya melihat hasil analisis statistik nilai $\mathrm{R}$ regresi $=0$, 996. Nilai tersebut menunjukan bahwa hubungan religiusitas dan kepribadian sebagai variabel moderator seseorang terhadap perilaku toleransi sangat kuat. Religiusitas dan kepribadian sebagai variabel moderator memprediksi perilaku tolerasnsi dengan hasil analisis statistik nilai $R$ Square menunjukan $\left(\mathrm{R}^{2}\right)=0$, 991. Nilai tersebut menunjukan bahwa religiusitas dan kepribadian sebagai variabel moderator memberikan konstribusi pada perilaku toleransi sebesar 99,1\%. Nilai tersebut menunjukan bahwa ada variabel yang lain yang memberikan konstribusi pada perilaku toleransi seseorang sebesar 0,09\%.

Hasil analisis yang lain dilihat dari tiga variabel yang masuk dalam regresi. Variabel religiusitas memiliki nilai koefisien parameter negatif $=-0,010$ dengan hasil tidak signifikan $p=0,643(p<0,01)$ terhadap perilaku toleransi. Variabel kepribadian memiliki nilai 
koefisien parameter negatif $=-0,752$ dengan hasil signifikan $\mathrm{p}=$ $0,000(\mathrm{p}<0,01)$ terhadap perilaku toleransi. Variabel moderat yang merupakan interaksi antara variabel religiusitas dan kepribadian memiliki nilai koefisien parameter positif $=0,013$ dengan hasil signifikan $\mathrm{p}=0,000(\mathrm{p}<0,01)$ terhadap perilaku toleransi. Jika hasil analisis statistik menunjukan bahwa variabel moderat signifikan, maka variabel kepribadian merupakan variabel moderator. Hal yang demikian memiliki makna bahwa ada interaksi antara variabel religiusitas dengan variabel kepribadian terhadap perilaku toleransi seseorang. Maknanya semakin berpengaruh variabel religiusitas terhadap perilaku toleransi, maka variabel kepribadian semakin berpengaruh terhadap perilaku toleransi orang tersebut.

Persamaan nilai regresi nilai konstanta sebesar 58, 723 nilai tersebut memiliki makna jika semua variabel independen memiliki nilai 0 (nol) maka nilai variabel perilaku toleransi sebesar 58, 723. Nilai tersebut memiliki makna bahwa perilaku toleransi responden penelitian dengan mengabaikan religiusitas dan kepribadian serta variabel moderator telah memiliki nilai sebesar 58, 723. Nilai tersebut menunjukan bahwa selain peran religiusitas, kepribadian dan variabel moderat terdapat peran variabel lain terhadap perilaku toleransi responden penelitian.

Nilai koefisien regresi untuk variabel religiusitas sebesar -0,010. Nilai tersebut memiliki makna bahwa ada penurunan satu poin religiusitas terhadap perilaku toleransi sebesar -0,010. Nilai koefisien regresi untuk variabel kepribadian sebesar -0,752. Nilai tersebut memiliki makna bahwa ada penurunan satu poin religiusitas terhadap perilaku toleransi sebesar -0,752. Nilai koefisien regresi untuk variabel moderator (interaksi religiusitas dan kepribadian) sebesar 0,013. Nilai tersebut memiliki makna bahwa ada peningkatan satu poin variabel moderator terhadap perilaku toleransi sebesar 0,013.Nilai tersebut memiliki makna bahwa semakin tinggi interaksi religiusitas dengan kepribadian responden, maka semakin tinggi perilaku toleransi responden. Responden memiliki religiusitas yang tinggi dan kepribadian yang tinggi akan meningkatkan perilaku toleransi responden tersebut, dibandingkan dengan responden 
yang tidak memiliki perilaku toleransi yang tinggi. Hasil tersebut dapat disimpulkan terdapat hubungan positif antara interaksi variabel religiusitas dengan variabel kepribadian sebagai variabel moderator terhadap perilaku toleransi responden.

Berdasarkan hasil analisis statistik nilai beta (B) interaksi religiusitas dengan kepribadian sebagai variabel moderator mampu menjadi prediktor perilaku toleransi secara signifikan $\mathrm{p}=0,000(\mathrm{p}<$ 0,01) dengan nilai beta (ß) sebesar 1, 224.

\section{Pembahasan Penelitian}

Hasil penelitian hipotesis minor berdasarkan hasil analisis statistik regresi menunjukan bahwa agama tidak berpengaruh terhadap perilaku toleransi seseorang merupakan fakta yang tidak dapat dibantah. Konteks yang demikian perlu disadari oleh semua pihak pemeluk agama. Banyak pemeluk agama yang masih rajin beribadah setiap hari, pergi ke tempat beribadah, dan rajin membaca teks-teks kitab suci, namun pemahaman makna perilaku ajaran toleransi antar sesama ataupun yang berbeda ajaran agama kurang banyak dipahami. Pemahaman agama yang dilakukan oleh para pemeluk agama lebih banyak menggunakan rasa fanatik bukan keyakinan perdamaian, ketenangan dan kesantunan.

Hasil analisis statistik penelitian di atas tentunya tidak serta merta sebuah wacana, tetapi merupakan fakta. Menurut Madjid (1995 : 90) bahwa kaum cendekiawan agama harus selalu memikirkan etika moral penganut agama. Hal yang tidak kalah pentingnya juga memikirkan bagaimana para pemeluk agama meresapi dan memahami makna dan tujuan hidup berkaitan dengan ajaran agama. Para pemeluk agama tidak hanya melaksanakan agama secara formalistik, namun para pemeluk agama meningkat pada pengamalan ajaran agama yang dapat mengambil sebuah makna. Apabila penganut agama menjalankan ajaran agama tidak hanya formalistik belaka, maka agama dapat memberikan sumbangan pada perilaku perilaku toleransi orang tersebut. 
Hasil penelitian ini bertentangan dengan hasil penelitian yang lain berkaitan dengan agama. Hasil penelitian menunjukan bahwa religiusitas tidak berpengaruh secara langsung terhadap agresi relasional mahasiswa, namun religiusitas berpengaruh secara langsung terhadap perilaku pemaafan (Hasan, 2013 : 10). Dalam konteks fenomena demikian dapat disimpulkan bahwa ada faktor yang belum sempurna pemahaman dan pengamalan seseorang terhadap agamanya. Artinya bahwa pengembangan pemahaman etika kehidupan toleransi dalam ajaran agama perlu ditingkatkan.

Di antara faktor yang perlu dipikirkan untuk meningkatkan pemahaman makna ajaran agama bagi para pemeluk agama adalah faktor pendidikan. Menurut Rahman (1965 : 272) bahwa dalam pendidikan madrasah kurikulum madrasah banyak yang diredusir yang merugikan umat Islam sendiri. Akibatnya para pemeluk agama memiliki pandangan yang sempit pada setiap ajaran agama yang diyakininya. Kejadian yang demikian ditulis oleh Katib Chelebi seorang penulis dari Turki (w.10-67H/1657 M) yang meratapi kelayuan sains-sains rasional, bahkan pemaknaan teologi. Pernyataannya "...tetapi banyak orang yang tidak cerdas yang pasif seperti batu-batu, membeku dalam peniruan nenek moyangnya. Mereka dianggap sebagai orang yang terpelajar, padahal mereka selamanya orang-orang yang jahil. Mereka senang sekali mencemooh apa yang mereka sebut sebagai sains filosofis, padahal mereka tidak mengetahui apa-apa tentang langit dan bumi.

Analisis hasil penelitian ini yang selanjutnya adalah kepribadian sebagai variabel moderator antara religiusitas seseorang terhadap perilaku toleransi berpengaruh secara signifikan. Artinya bahwa semakin seseorang memiliki keagamaan yang baik dan semakin kepribadian yang baik berpengaruh terhadap perilaku toleransi seseorang. Memahami hasil analisis variabel kepribadian moderator menunjukan hasil yang berbeda ketika hanya ada pengaruh variabel religiusitas terhadap perilaku toleransi yang tidak signifikan. Artinya bahwa interaksi antara variabel religiusitas 
dengan variabel kepribadian memenuhi syarat sebagai variabel moderator terhadap sikap toleransi.

Hasil penelitian penelitian ini seiring dengan hasil penelitian yang lain yaitu ada hubungan religiusitas dan kepribadian yang berpengaruh terhadap nilai-niliai etika penganut agama tersebut. Tema-tema yang demikian sering dikaji dalam psikologi agama. Tema-tema yang demikian dapat memberikan inspirasi mengembangkan kajian pada psikologi agama berkaitan dengan pandangan psikoanalisis, psikologi sosial, dan psikologi kognitif. Pembahasan pembahasan yang demikian diharapkan dapat mengembangkan psikologi agama, psikologi kepribadian untuk dapat menyajikan taksanomi kepribadian seseorang (Saroglou \& Jaspard, th : 41).

Hasil penelitian ini juga didukung dengan hasil penelitian yang lain. Hasil penelitian menunjukan bahwa kepribadian yang bermoral dan identitas moral berhubungan dengan etika individu. Makna yang terkandung bahwa seseorang yang memiliki kepribadian yang baik dan identitas yang baik (agama) akan berpengaruh pada perilakunya dengan menjunjung tinggi etika kehidupan. Penelitian yang lain menunjukan idiologi menjadi variabel mediator antara kepribadian dan identitas moral. Maknanya bahwa semakin baik kepribadian seseorang dengan idiologi dimilikinya maka orang tersebut akan memiliki perilaku moral yang baik (Mc Ferran et al, $2010: 35)$.

Hasil penelitian ini sangat baik dikembangkan di Indonesia. Indonesia merupakan negara yang memiliki ragam agama dan kepercayaan yang berbeda-beda. Walaupun kondisi yang demikian warga Negara Indonesia hidup dengan damai rukun dan santun antar pemeluk agama dan kepercayaan. Menurut menteri luar negeri Italia Franco Frattini dan para pendiri komunitas Sant' Egidio, Andrea Riccardi mengemukakan dalam pidatonya ketika pembukaan seminar Internasional pada tahun 2009 dengan tema 
Unity in Diversity: The Indonesian Model for a Society in which to Live Together. Beliau mengatakan bahwa Indonesia mampu menjadi laboratorium kerukunan antar umat beragama. Keadaan yang demikian merupakan pengakuan dunia. Kejadian demikian karena adanya agama dan kepribadian yang berpengaruh terhadap perilaku toleransi (Komunika, $2011: 1$ ).

\section{Kesimpulan}

Agama merupakan keyakinan seseorang yang berpengaruh terhadap perilaku para penganutnya. Pemahaman dan pemaknaan ajaran agama yang baik akan berpengaruh pada etika moral yang dijalankan setiap harinya. Di antara etika moral dalam kehidupan sehari adalah perilaku toleransi terhadap sesama agama ataupun yang berbeda agama. Pelaksanaan ajaran agama yang formalistik tidak akan banyak berpengaruh pada kepribadian menjadi lebih baik. Dengan demikian peningkatan pemahaman dan pemaknaan ajaran agama dengan menjunjung tinggi kesadaran perilaku toleransi sangat penting untuk dikembangkan. Apalagi Indonesia memiliki warga Negara yang memiliki keragaman agama, suku, dan ras. Peningkatan pemaknaan perlaku pengamalan ajaran agama akan mempengaruhi kepribadian seseorang dan perilaku toleransi orang tersebut.

\section{Daftar Pustaka}

Asy'arie, Musa. 2005. Islam Keseimbangan Rasionalitas, Moralitas, dan Spiritualitas, Yogyakarta: LESFI.

Carter, Evan C., Mc Cullogh, Michael E., \& Carver, Charles S. 2012. The medating role of monitoring in the association of religion with self control, Social Psychological and Personality Science, 3 (6) 691- 697. 
Ekinci, Yuksel., Calderon, Joana., \& Siala, Haytham. 2000. Do Personality traits predict complaining consumers?. International Business Environment, Vol.X No. XXXX, 1-11.

Hasan, Aliah B Purwakania, 2013. Pemaafan sebagai variable moderator pada pengaruh religiusitas dengan agresi reasional dikalangan Mahasiswa Universitas berbasis nilai-nilai Islam, Jurnal Al-Azhar Indonesia Seri Humaniora, Vol.2 No.1, 1020.

Heaven, Patrick, C.L., \& Ciarrochi, Joseph. 2007. Personality and religious values among adolescents: A Three - wave longitudinal analysis, British Journal of Psychology, 98.681694.DOI: 10.1348/000712607x187777.

Ismail, Roni. 2012. "Konsep Toleransi Dalam Psikologi Agama (Tinjauan Kematangan Beragama)", dalam Jurnal Religi, edisi Vol. VIII, No.1, 2012.

Komunika, 2011.Keberagaman Kekuatan Bangsa Untuk Maju, edisi VII, Maret 2011, 1-10.

Madjid, Nurcholish. 1995. Islam Agama Kemanusiaan, Membangun Tradisi dan Visi Baru Islam Indonesia, Jakarta: Paramadina.

Mc Ferran, Brent., Aquino, Karl., \& Duffy, Michelle. 2010. How Personality and Moral Identity Relate to Individuals' Ethical Idiology, Business Ethics Quarterly, ISSN 1052 150X, pp.3556.

Rahman, Fazlur. 1965. Islam, Bandung : Pustaka.

Rubin Jennifer., Taylor Jirka., Pollitt Alexandra., Krapels Joachim., \& Pardal Mafalda. 2014. Intolerance in Western Europe, Analysis of trends and associated factors, The research described in this report was supported by grant from the Open Society Foundations. 
Saliyo. 2017. Bimbingan Konseling Spiritual Sufi dalam Psikologi Positif, Yogyakarta : Best Publisher Galang.

Saroglou, Vassilis., \& Jaspard, Jean Marie, tth. Personality and Religion, Research reported in this paper was facilitated by a grant from The Belgia National Fund for Scientific Research.

Saroglou Vassilis., Delpierre Vanessa., \& Dernelle Rebecca. 2004. Values and religiosity: a meta-analysis of studies using Schwartz's model, 37, 721-734.

Shihab, Quraish. 1992. Membumikan al-Qur'an, Bandung: Mizan.

Simuh, Ridin Sofwan. 2004. Merumuskan Kembali Interelasi IslamJawa, Semarang: Pusat Kajian Island an Budaya IAIN Wali Songo.

Thouless, Robert H. 1995. Pengantar Psikologi Agama, diterj oleh Machnun Husein, Jakarta: Raja Grafindo Persada. 